\title{
Universalization of the International Relations in the Context of Formation and Activity of the League of Nations
}

\author{
Roman V. Penkovtsev ${ }^{1}$ \\ ${ }^{1}$ Kazan (Volga Region) Federal University, Kazan, Russia \\ Correspondence: Roman V. Penkovtsev, Kazan (Volga Region) Federal University, 420008, Kazan, \\ Kremlyovskaya Street 18, Russia. E-mail: Roman.Penkovtsev@kpfu.ru
}

Received: June 2, 2015 Accepted: June 15, 2015 Online Published: June 29, 2015

doi:10.5539/jsd.v8n5p92 URL: http://dx.doi.org/10.5539/jsd.v8n5p92

\begin{abstract}
The urgency of the problem under study is caused by the fact that in 2014 it had been 100 years from the moment of the beginning of the World War I, the war of an absolutely new type which put mankind on the edge of total disappearance on scales of victims and destructions. At the same time this war forced to change the character of international relations completely, having made them more open and directed to establishment of a settled dialogue. The article is directed to studying the role of the League of Nations in the processes of universalization of the international relations during the interwar period, its attempts to create the international political tools which would allow to remove completely or essentially the threat of a new war. The leading approach of the research of this problem is a system approach, as this approach allows when studying the evolution of the international organizations (including the Leagues of Nations) to use various scientific methods and techniques in complete, mutually supplementing and combining them. The main results of the research testify that World War I, being one of the greatest tragedies in the history, became at the same time the catalyst of the progressive political processes which put the foundation of a new world system, based on understanding of mutual dependence and aspiration to general safety. The most important instrument of providing the lasting post-war peace was urged to become the League of Nations. The materials of the article can be useful for preparation of educational, methodical and scientific literature and used also in the educational process as it contains theoretical information and set of empirical data on the problem of creation and functioning of the universal regulating international organizations on an example of the League of Nations.
\end{abstract}

Keywords: International relations, World War I, "Fourteen points", Versailles conference, the League of Nations, Wilson, Lloyd George, Clemenceau, Orlando, international organization

\section{Introduction}

The ideas of creation of the ideal international organization, urged to guarantee lasting peace and safety to the peoples, were repeatedly put forward by the representatives of political and philosophical thought. Thomas More, Hugo Grotius, Immanuel Kant are known for the reflections about qualitative essence of empires and possible ways of ensuring the international security (Ostrower, 1996). It was I. Kant, perhaps, who most clearly understood the logic of this development at the end of the XVIII century and drew conceptual conclusions: «The influence, which shakes each state in our part of the world so closely, exerting on other states so considerably that these states under the pressure of danger threatening them, though without the lawful basis, offer themselves as arbitration judges and thus from far away prepare for future great state association» (Kant, 1991).

As a rule, the projects of creation of the international integrated systems appeared during the most tensed moments of the world history, during multinational wars and conflicts. Thus an attempt to create the structure for maintenance a strong order on the European continent was carried out in 1814-1815 on the Vienna congress. Having agreed about convocation of regular conferences on the European stability, Holy Alliance created an essentially important precedent. At the same time it became the very first option of that «great political body» which was foreseen by Kant (Palmer \& Colton, 1965). However the projects on creation of the regulating organizations on a global scale could not find practical application up to the XX century. The states of Europe continued developing imperial forms whereas they were to be audited sufficiently over the ocean. The topic of the European crisis turned into a discourse about the fall of the Empire and became entangled with the topic of the crisis of democracy and also the issues of the forms of consciousness and resistance generated by this crisis. 
Alexis Toquil was probably the first who detailed the problem in this way. In his opinion the reason of the crisis of European civilization and its imperial habits consisted in the fact that the European virtue - or its aristocratic moral issued at the institutes of modern sovereignty, - is unable to go equally with vital forces of mass democracy (Toquil, 1992). The United States offered an alternative in the form of the Pax Americana project proclaimed by the liberal leaders and dressed in a form of the American dream of social mobility and equal opportunities for achievement of wealth and freedom. In the XIX century the universalizm became one of the leading foreign policy principles of the United States as it was formulated by the president T. Jefferson: it is necessary to serve «a torch of freedom» for the whole world, but never to apply force, but only to influence the others with the example (Sheldon, 1996). There always used to be an element of naive belief in the American universalizm that everything suitable for America, suits the rest of the world as well.

In the second half of the XIX century colonel A. Mekhen openly preached the theory of the world arbitrator the role of which should be played by the strongest state. The colonel attributed the USA «a priority of interference» in affairs of the other countries of the world, referring to the "force" - military force and force of the "position", i.e. a geographical position. He considered that in the future a hard-fought battle for the new markets and raw materials sources would break out and this fight would inevitably demand the use of military force to open and win the new markets. A historical mission of the United States is to be the tool of the expansionism predetermined by destiny (La Feber, 1963). The idea of the necessity to create international regulating agreements and organizations was expressed for the first time at the turn of the XIX-XX centuries. The Hague court can somewhat serve a prototype of such international organization. But because of its functional limitation, which is reduced to legal arbitration of recommendatory character, it appeared not to be ready to react adequately to preparation for a new big war carried out by leading states. Thus, this is the period when «internationalism confidently starts to divide a political scene with traditional nationalism» (Ostrower, 1996), but the latter continued playing a significant role. From the beginning of the World War I contradictions of national interests of the European states involved in the hostilities aggravated considerably. Tendencies to internationalization of the international relations got certainly into acute crisis. The United States of America tried to carry out a non-interference policy at the initial stage of the war, reserving the right to act as the international arbitrator.

During World War I which concerned the interests of many states, there appeared some European projects of future peaceful settlement. The slogan that the good will of the united nations should triumph over force, found support in Great Britain (the project of lord J. Brays), Greece (the offer of E.Venizelos) and other countries. Some part of these plans concerned only regional, first of all European, interests, others envisaged the creation of the universal international organization. And still the functional bases of the organization of this sort could not be fixed in the conditions of the military conflict.

Besides at the period of the World War I the political and economic balance of the forces changed essentially on the world scene. The European countries sustained huge human, financial and economic losses, spent the international authority which had been saved up for the previous century. The USA, on the contrary, practically were not affected by the military events and acquired big political and, especially economic, weight. That fact is doubtless that during these crisis years the States turned into the leading industrial and financial force and became the richest state on the planet. The conditions were being created to enable Washington to put forward plans of the settlement of the conflict and to demand them to be treated with all gravity. At the initial stage of the war president V. Wilson had already emphasized the urgency of signing the peace treaty followed by post-war agreements on creating a commonwealth of the countries, excluding the possibility of repetition of similar catastrophe.« It is absolutely necessary to establish a force which would exceed the force of any state or group of states as the guarantee of firmness of the international agreement and that no separate state or a possible combination of states could confront it», - V. Wilson declared(Baker \& Dodd, 1926). Thus, the United States acted the generator of new principles of the international relations at a turning point of human history.

Wilson's speech to the League of the defense of peace, made in May 1916 became some kind of program performance concerning foreign policy. The league of the defense of peace was founded in Philadelphia in May 1915, it had the interstate status, and ex-president of the USA W. Taft was elected the chairman. All the states interested were invited to participate in it on a voluntary basis. The league declared: prevention of any aggression in the relations between the members, the procedure of intermediary investigation and the trial of the world community. On the occasion of the anniversary of its foundation Woodrow Wilson made a speech in which for the first time put forward the idea of creation of the post-war international organization - the League of Nations and formulated its basic principles which consisted in maintaining the order and control over the observance of the "rules of the game" in an international scale.

The aspiration to create the League of Nations meant for the USA, firstly, recognition of insolvency and refusal 
of isolationist doctrines, secondly, their universalization of the Doctrine of Monroe for all mankind, thirdly, the declaration of the USA claims on establishment of world hegemony. Thus, the White House offered the world a compromise alternative to a well-known earlier «peace in a German way» and «peace in a British way». The developed economic power allowed America to reject a rigid euro-centrizm in world politics.

\section{Methodological Framework}

At the final stage of the World War I the American president W. Wilson started practical embodiment of a new system of the international relations. On January 8, 1918 he explicated well-known «Fourteen points» in the message to the American congress. Their considerable part had an innovative character, but there were also the ones declared before as the abstracted philosophical and political ideas. The historical value of «Fourteen points» consists in integrative character of this program, its practical applicability to a moment structure. When studying the document it is obvious that its separate paragraphs are non-uniform in essence. Some of them are local, others are universal, but all are subordinated to uniform logic. According to the program, it is possible to construct a certain synthesized model of an ideal law and order offering the decision to the most acute problems of mankind.

The first aspect of the program is connected with providing lasting peace and safety. The second aspect was urged to provide mainly stability of political conditions for the international economic relations which would allow the USA, turning into the largest trading and financial power, to dominate in the world economy, to force out the European empires for the secondary roles. At last, the third aspect of «Fourteen points» was urged to solve the thorniest territorial questions on the basis of the principles of national equality and justice. Recognition lawful the pursuit of acquiring sovereignity for small nations from great empires leads to foundation of the whole galaxy of new autonomies and states in Europe and around the world. The central place in the program "Fourteen points" was given to creation of the League of Nations (Seymour, 1944).

«Fourteen points» were formulated by W. Wilson as practical initiatives for completion of war and bases of the post-war organization. However, it is erroneous to treat them only in a context of processes of post-war settlement. The program pursued the far-reaching aims which could not be solved directly upon termination of operations. By the time of the end of the World War I "Fourteen points" gained wide international recognition and support, and quite naturally became a basis of negotiation process in 1919 at the Versailles peace conference.

Opening the Versailles conference, the participants adopted the resolution providing the need of creation of the League of Nations and inclusion of its charter in the text of the peace treaty. "We have gathered here for the sake of two purposes: for preparation of settlement which became obligatory as a result of this war and also for providing and peacekeeping on the earth. The League of Nations is necessary for the achievement of these two purposes" (Papers Relating to the Foreign Relations of the United States, 2013), - the participants of the negotiations declared. However extreme complexity of the process of universalization of the principles of international relations was defined at the very first meetings. The program offered by Woodrow Wilson was subjected to considerable criticism from the European leaders, what is quite explainable if to consider that there were also British and French projects on creation of the League besides the American one.

In the English project the League was treated as the union and the disputes between member states should be regulated by the arbitration court and consequently the extent of the international integration remained low. The French offers were more resolute. They included the detailed list of measures of impact on an aggressor up to military coercion to peace. France insisted on necessity to allocate the League of Nations with armed forces which would consist of armies of various member states (Novak, 1930). It is obvious that the projects of the USA, Britain and France differed essentially, each party considered the option as the main and optimum that generated fierce disputes at the peace conference.

There were basic disagreements of the criteria by means of which it would be possible to qualify the actions of the party as attackers. The concepts "aggression" and "aggressor" were introduced into the Statute of the League of Nations, though their interpretation was not developed enough. It was qualitatively new that an obvious difference was proclaimed between an attacking party (aggressor) and the victim of aggression, which could be the reason for rendering the collective help to the victim. Despite this important achievement the Statute could not find the article unconditionally forbidding any forms of aggression. The League preferred to discuss in detail collective sanctions against an attacking party, but did not try to give a clear idea on the criteria of «aggressive behavior»(Antonov, 1937). At the same time, absence of a conventional interpretation generated inconsistent unusual cases, - in each separate conflict the Council of the League of Nations was compelled to make a particular solution and not always an adequate one. Whereas W. Wilson was convinced that « collective security was the heart of the League of Nations» (Cooper, 2001) and despite a lot of work done by the special 
commissions in the 1920th, the offers on mutual help and guarantees of collective security were also rejected. As a result of the unresolved issue the universalistic concept remained doubtful. It was not considered incommutable that all the states without any exception should be involved in the international system of safety and their actions should be consolidated, not selective, depending on private interests and momentary calculations.

A debate was also caused by a question of the international armed forces creation. The prime minister of Great Britain D. Lloyd George believed that possible sharp military strengthening of France at the expense of the international forces in Europe was against the interests of Britain. Thus the French offer on resolute military sanctions against an aggressor was rejected. In his turn Wilson was steadily pressed by the American isolationists in the Congress who opposed strongly against the involvement of the States in the organization, urged to provide the international security. Various coalition of forces (representatives of Republican Party, a group of "irreconcilable") united with the purpose not to allow participation of the USA in the League of Nations. They urged not to connect themselves with obligations in relation to other countries and not to contract alliances with them. Article 10 obliged the members of the international organization «to respect territorial integrity and political independence of all the members of the league» and in case of attack, threat or danger of attack demanded from the League Council «concrete measures for ensuring implementation of this obligation» (Baker \& Dodd, 1927). Wilson's opponents proved that it will force the USA to refuse traditional policy of neutrality, act them into the abyss of the European conflicts, cause damage to the American sovereignty and will fix dominating positions in the League to England and France.

Thus, on an initial stage of its foundation the League of Nations lost one of the most effective forces for peacekeeping and safety. Disagreements between the main participants of the conference lead to the fact that each new compromise amendment reduced the effectiveness of the League of Nations, making it capable only to establish the fact of breach of peace, having no possibility to react on it adequately. According to article 16 of the Statute of the League of Nations the vague statement of « rapture of all trade and financial relations» became the only measure of impact on an aggressor. Therefore the members of the League were ready to oppose only economic sanctions to the armed breach of peace. Later, in 1924, the Geneva protocol on exclusively peaceful resolution of the international disputes was signed. It was confirmed that the participating countries «have the right to resort to a war only if they undergo an attack and besides only with the consent of the League of Nations» (Antonov, 1937). All this facilitated the actions of aggressors extremely.

Another serious problem for the League of Nations became an extremely complicated system of development of decisions. According to the Statute the supreme bodies of the League were the Assembly (all member states of the League were its participants) and the Council where permanent members (winner countries) and temporary ones (chosen by the Assembly) met. According to points 3 and 4 of the Statutes the powers of these two bodies were treated absolutely equally, thus they possessed legal equality (Antonov, 1937). Besides direct duplication of the functions, that, naturally, did not promote dynamic office-work, both the Assembly and Council made decisions only on the basis of consensus. The voting procedure allowed any interested participating state to go contrary to the general will, breaking adoption of decisions unprofitable to it. There are no doubts that in the conditions of political blocking, characteristic for the international system of the XX century, any of the states, even aggressively adjusted, could count on the support from adherents or dependent satellites.

Considerable difficulties were generated by a question of mutual arms limitation. The process of international disarmament could compensate in a certain measure the mechanism of military coercion of an aggressor to peace unrealized in the Statute. If the process of reduction of the armed potentials became obligatory and transparent, the chances of emergence of the large-scale conflicts would considerably go down (Antonov, 1937). The first edition of the American project provided «reduction of national arms to a minimum compatible to internal security». Moreover W. Wilson suggested at a certain stage to cancel obligatory military service in general. But such offers did not cause sympathy from the British and Japanese delegations. Under their pressure article 8 recommending the processes of disarmament "to a minimum compatible to national security" was fixed in the Statute of the League. Definitions of "internal" and "national" security differed strikingly. The latter had obviously an abstracted general character and could vary depending on political structure of the moment, existence of real or hypothetical threats to national tranquility. In the final variant article 8 was consolidated only to kind wishes and did not interfere at all with the race of arms. In the 1920-30th various conferences on disarmament questions were repeatedly convoked within the League, some working commissions operated, but their work did not bring any practical results.

Despite numerous obstacles, the final compromise version of the Statute of the League of Nations was made and unanimously accepted on April 281919 at the fifth plenary session of the Versailles peace conference. As the 
major component it was included into the text of the peace treaty as well as into all subsequent contracts of new arising system of the international relations - Washington, Treaty of Saint-Germain-en-Laye , Treaty of Neuilly-sur-Seine, Treaty of Trianon, etc. By the definition of the professor R. Henig the establishment of the League of Nations was one of the most significant political achievements of the end of the 19th - the beginning of the 20th centuries." It has become a symbol of hopes for millions of people worldwide that their sacrifices will not appear vain and that after the end of a war strong peace will come " (Henig, 2010). Initially the League united 40 states and independent colonies, later their number increased. The number of permanent members of the Council included Great Britain, France, Italy and Japan. The countries -members of the League occupied about $63 \%$ of the territory of the globe, about $70 \%$ of the population of a planet lived in them.

\section{Results}

The evolution of the League of Nations during the interwar period is interfaced to a set of problems of institutional and functional character. The international community submitted for the court a set of questions demanding immediate solving. And its first actions were characterized by extreme indecisiveness, inconsistency and low degree of efficiency. From the first days of its existence the international credibility of the organization was rather low because two largest states - the United States of America and Soviet Russia did not participate, that aggravated considerably the shortcomings contained in the Statute of the League. The negative attitude to the Soviet Russia which had turned up at the Versailles conference led to intervention policy and consequently to long years of its non-recognition. The further course of history will confirm an inaccuracy of anti-Soviet decisions from the founders of the League of Nations.

The problem of refusal of the USA from participation in the League of Nations is supposed to be more complicated and on its example it is possible to reveal the sharp conflict of the American legislative and executive branches of the power. The senate of the USA counteracted greatly to presidential initiatives on overcoming the policy of isolationism and promotion of the American state for the leading roles in the world politics. The chairman of the committee of the international affairs the republican G. Lodge subjected Wilson's European policy to rigid criticism and broke ratification of the text of the Versailles contract. The arguments of the opponents of the League of Nations in the Senate of the USA are hard to recognize convincing as they concerned, first of all, the 10th article of the Statute (about collective actions against an aggressor) which had only a recommendatory character. From the point of view of conservative republican senators these debates were basic as they concerned constitutional and legal competences of the Congress in a question of declaration of war. They believed that guarantee certificates of the League of Nations would contribute to essential expansion of presidential powers in the solution of the international and military-political questions. It is impossible to disagree with the opinion of D. Lloyd George that «the first blow, which loosened the influence and authority of the League of Nations, was struck by America» (Lloyd George, 1957). It is necessary to admit the fact that at the beginning of the XX century the American political establishment was not ready yet to admit the processes of universalization in international policy, considering them unjustified and unpromising.

At the same time in Europe the foundations of democracies underwent powerful political and economic cataclysms which lead to frequent change of the governments and generated a gap in foreign policy succession concerning post-war doctrines. It was obvious that isolationist and pacifist currents strengthened and promoted the formation of a policy of appeasement concerning fascist regimes. Quite often pacifistic slogans covered political weakness or narrow state interests which started to prevail over allied solidarity and international guarantees again. Withdrawing from the process of impact on aggressive regimes, European democracies hoped that the institute of the League of Nations would be able to promote autonomously and effectively prevention and localization of the conflicts. It was hardly justifiable illusion.

The first half of the XX century showed frailty of the closed foreign policy systems, having offered alternatively the international consortiums and structures ready to dialogue. Conflicts shook the world, and they proved again the necessity to develop the mechanisms of interest rapprochement, principles of peaceful co-existence and foundation of the global regulating organizations. The League of Nations tried to be first of all a regulatory organ, but as a result lost even its unifying function. A low level of integration of the international community led to destruction of the Versailles system. The mankind needed to endure all horrors of a new world war in order to use ideology of universalizm of the beginning of the XX century on a qualitatively new level.

\section{Discussions}

The problem of universalization of the international relations in the XX century and activity of the League of Nations as the integral and major part of this process traditionally draw attention of researchers. The scientific community was divided into consecutive apologists of the process of formation of unified international 
principles of behavior and its irreconcilable opponents for who considered loss of national identity unacceptable. Each separate aspects of evolution of the League of Nations caused heated scientific debates producing sometimes concrete and practical offers on transformation of the system of the international relations which had developed in the first half of the XX century.

An American professor L. Ambrosius, for example, finds in the program «fourteen points» some elements of the new foreign policy vision which deny a priority of military force in the international affairs and aspire humanization of the international relations in the process of improvement of a human civilization (Ambrosius, 2002). Another American researcher - M. Macmillan, characterizing the position of the USA at the Versailles peace conference, is sure that President Wilson «carried the best world order to the European peoples» (Macmillan, 2002). Similar views are stated by an Italian historian D. Esposito, criticizing vigorously «the European national pragmatists» in the person of D. Lloyd George, J. Clemenceau and V. Orlando, who «were not inclined to share universal idealism being the basis of Wilson's foreign policy» (Esposito, 1996). A number of authors, in particular a professor of Princeton university T. Knock, are inclined in general to identify the idea of creation of the League of Nations with messianism and to give it the character of neo Bible doctrines. From their point of view «the Christian doctrine played considerable, if not crucial role in political reasonings» touching upon the need of creation of the League of Nations (Knock, 1995).

A group of researchers have totally opposite point of view. They find the processes of universalization of the international relations typical for the first half of the XX century negative and even dangerous to mankind. So, an outstanding American political scientist Hans Morgenthau, arguing about universalistic Wilson's initiatives, comments that «the claims on universality on which the moral code of one group in the international community is based are absolutely incompatible with similar claims of another group. There is some place for one group of the kind in the world and another one should either obey or be destroyed» (Morgenthau, 1948). Similar views are stated by a prominent German historian Charles Schmidt who considered «the formation of the League of Nations to be disintegration of dominating principles of international law» and formation of universalistic Versailles and Washington system «basing, first of all, on Wilson's (i.e. American) principles» (Schmitt, 1950). The American political scientist neo-Marxist Nicolai fon Kreytor is even more critical in estimating the idea of creating the League of Nations. He believes that the universalizatoring rhetoric is only a cover for achieving the pragmatic purposes of the White House. «Universalizm in practice developed the idea of absolute power of one country, covering it with ideological concepts of natural state of the world society. The establishment of world supremacy of universalizm is ennobled to the status of a sacred doctrine in which the truth and the right are identical with traditional national interests of the USA (Kreytor, 2000), - Kreytor writes.

In this article an objectified view upon the activity of the League of Nations on universalization of the international relations is reflected. From our point of view the process of formation of the international institutes, like the League of Nations, is inevitable and natural according to the logic of development of the system of the international relations. At the same time, the aspiration of the USA to subjugate the process of formation of the League of Nations according to their foreign policy principles, first of all the doctrine of Monroe, is obvious to us. Thus, universalizm of the first half of the XX century obviously consists not only in the moral and ideological purposes of general progress and reconciliation, but quite pragmatic ones as well which allow the USA to expand the borders of their influence on world politics.

\section{Conclusion}

For the years of its existence the League of Nations used to face with numerous facts of a breach of peace and direct aggression. The majority of these aggressive acts were considered by the League of Nations through a prism of activity of numerous commissions, committees, conferences and adopted resolutions unfounded and causing no practical results. It was the way leading to non-interference policy following which the League of Nations preferred to watch the succession of events instead of being their active participant and regulator. There was no unity among the leaders of the western democratic parties, each of them aspired to provide national interests and safety in the conditions of new ripening crisis. Aggression acts against other countries were either not noticed or became a bargaining object with an aggressor. Each step on the way of a non-interference policy struck a crushing blow to the international prestige of the League of Nations. Breaking out a new much more terrible World War II by the fascist states became a predictable ending of such policy. By the beginning of the war the international regulating role of the League of Nations was obviously recognized settled. The organization did not justify the duties of peacekeeping and safety imposed on it. The militarism of the countries aggressors and passivity of the League of Nations destroyed the Versailles and Washington system of the international relations as a whole. April 18, 1946 the League of Nations was formally dismissed and stopped the existence. 


\section{Acknowledgments}

The work is performed according to the Russian Government Program of Competitive Growth of Kazan Federal University.

\section{References}

Ambrosius, L. E. (2002). Wilsonianism: Woodrow Wilson and His Legacy in American Foreign Relations. New York, NY: Palgrave MacMillan, 256. http://dx.doi.org/10.1057/9781403970046

Antonov, K. V. (1937). Security guarantees under the statute of the League of Nations. Collection of documents on international politics and international law. Issue XI. Moscow, USSR. Publication of the People's Commissariat of Foreign Affairs, 394.

Baker, R. S., \& Dodd, W. E. (Eds.). (1926). The New Democracy. Presidential Messages, Addresses and other Papers (1913-1917) by Woodrow Wilson (Vol. 2). New York, NY: Harper \& Bros., 483.

Baker, R. S., \& Dodd, W. E. (Eds.). (1927). War and Peace Presidential Messages, Addresses, and Public Papers (1917-1924) by Woodrow Wilson (Vol. 2). New York, NY: Harper \& Bros ., 674.

Cooper, J. M. (2001). Breaking the Heart of the World: Woodrow Wilson and the Fight for the League of Nations. Cambridge: Cambridge University Press, 466.

Esposito, D. M. (1996). The Legacy of Woodrow Wilson: American War Aims in World War I. Westport, Conn .: Praeger Publishers, 176.

Henig, R. (2010). League of Nations: The Makers of the Modern. London: Haus Publishing, 224.

Knock, T. J. (1995). To End All Wars: Woodrow Wilson and the Quest for a New World Order. Princeton, NJ: Princeton University Press: Praeger Publishers, 400.

Kreytor, N. (2000). From Monroe doctrine to a "new world order". Marxism and modernity, 1(15), 57-73.

LaFeber, W. (1998). The New Empire. An Interpretation of American Expansion, 1860-1898. London: Cornell University Press, 325.

Lloyd George, D. (1957). The truth about peace treaties. V. 2. Moscow: Publishing House of Foreign Literature, 556.

Macmillan, M. O. (2002). Paris 1919: Six Months That Changed the World. New York, NY: Random House, 624.

Morgenthau, H. (1948). Politics among Nations: The Struggle for Power and Peace. New York, NY: Alfred Knopf: 489.

Novak, K. F. (1930). Versailles. Moscow: State Publishing House, 204.

Ostrower, G. B. (1996). The League of Nations: From 1919 to 1929. New York, NY: Avery Publishing Group, 176.

Palmer, R., \& Colton, J. (1965). A History of the Modern World. New York, NY: Alfred Knopf, 1248.

Papers Relating to the Foreign Relations of the United States. The Paris Peace Conference. Vol. 3. P. 178. (2013, October 12). In University of Wisconsin Digital Collections. Retrieved October 12, 2013, from http:/www.digicoll.library.wisc.edu/cgi-bin/FRUS/FRUS-idx?id=FRUS.FRUS1919Parisv03

Reiss, H. S. (Ed.). (1991). Kant: Political Writings. Cambridge: Cambridge University Press, 325.

Schmitt, C. (1950). Der Nomos der Erde im Volkerrecht des jus publicum Europaeum. Köln: Greven, 309.

Seymour, H. (Ed.). (1944). Archive of colonel House: Diaries and correspondence with President Wilson and other politicians during 1914-1917. T. 4. Moscow: OGIZ-Gospolitizdat, 404.

Sheldon. (1996). Thomas Jefferson's political philosophy. Moscow: Republic, 255.

Tokvil, A. (1992). Democracy in America. Moscow: Progress, 554.

\section{Copyrights}

Copyright for this article is retained by the author(s), with first publication rights granted to the journal.

This is an open-access article distributed under the terms and conditions of the Creative Commons Attribution license (http://creativecommons.org/licenses/by/3.0/). 